\title{
PENGARUH ERUPSI GUNUNG CIREMAI TERHADAP MORFOLOGI TATA RUANG KAWASAN PELABUHAN CIREBON PADA MASA KOLONIAL 1681 - 1942
}

\section{The Effect of Mount Ciremai Eruption on the Spatial Morphology of Cirebon Port Area during the Colonial Period 1681-1942}

\author{
Mustaqim Asteja \\ Komunitas Pusaka Cirebon Kendi Pertula \\ Jalan Tambas 2 No. 49 RT 01/ RW 02 Desa Pasindangan Kecamatan \\ Gunung Jati Kabupaten Cirebon Jawa Barat \\ E-mail: kendipertula@yahoo.com
}

\begin{abstract}
Cirebon was an ancient port city and the first Islamic Kingdom in West Java during the time of Sunan Gunung Jati (1448-1568). Initially the city of Cirebon was built on the Cirebon coast with a West - East orientation Angadep Jaladri Amungkur Giri, facing the ocean back to the mountains, namely Mount Ciremai (3.078 meter) the highest mountain in West Java Province. Moun Ciremai is a natural resource that forms the local topography an its innate elements, namely : geology, volcanology, climate, weather, flora, and fauna. This paper examines the effect of Mount Ciremai on the morphological development of Cirebon City spatial planning, especially Cirebon Harbor during the Dutch East Indies colonial period using archeologicalhistorical methods, field research around the Port of Cirebon and analyzed with historical archive sources. Lava and volcanic ash from the eruption of Mount Ciremai formed alluvial mud and increase sedimentation in the watershed, thus affecting the morphological development of Cirebon City spatial planning, especially Cirebon Port which initially utilized the Cirbon Revier.
\end{abstract}

Keywords: eruption, Mount Ciremai, morphology, Cirebon Harbor.

\begin{abstract}
Abstrak
Cirebon adalah kota pelabuhan kuna dan kerajaan Islam pertama di Jawa Barat pada masa Sunan Gunung Jati (1448-1568 M). Awalnya Kota Cirebon tumbuh di pesisir Cirebon dengan orientasi barat - timur Angadep Jaladri Amungkur Giri, menghadap lautan membelakangi pegunungan, yaitu Gunung Ciremai $(3.078 \mathrm{mdpl})$ gunung tertinggi di Provinsi Jawa Barat. Gunung Ciremai adalah sumber daya alam yang membentuk topografi setempat beserta unsur bawaannya yaitu: geologis, vulkanologis, iklim, cuaca, flora, dan fauna. Makalah ini mengkaji pengaruh erupsi gunung Ciremai terhadap perkembangan morfologi Tata Ruang Kota Cirebon khusnya Pelabuhan Cirebon masa kolonial Hindia Belanda dengan metode arkeologi sejarah yaitu penelitian lapangan di sekitar pelabuhan Cirebon dan dianalisis dengan sumber-sumber arsip sejarah. Lahar dan debu vulkanik akibat letusan gunung Ciremai membentuk lumpur aluvial dan mempertinggi sedimentasi di Daerah Aliran Sungai (DAS) sehingga mempengaruhi perkembangan morfologi tata ruang Kota Cirebon, terutama Pelabuhan Cirebon yang awalnya memanfaatkan sungai Cirbon Revier.
\end{abstract}

Kata kunci: erupsi, Gunung Ciremai, morfologi, Pelabuhan Cirebon. 


\section{PENDAHULUAN}

Eksistensi Cirebon sebagai kota bandar kuna di pantai utara wilayah Jawa Barat telah dikenal dan tercatat dalam manuskrip setidaknya sejak awal abad XV. Manuskrip Cina Shun-Feng Hsiang - Sung sebuah buku pedoman pelayaran yang disusun \pm tahun $1430 \mathrm{M}$ yang sekarang tersimpan di Bodleian Library (Oxford), menerangkan instruksi jalur pelayaran dari Shun-t'a (Sunda Pajajaran) ke arah timur sepanjang pantai utara menuju Che-Li-Wen atau Cirebon (Heuken, 1999).

Penulis Portugis Tome Pires dalam Suma Oriental (1513-1515) menerangkan tentang Pulau Jawa yang saat itu wilayahnya meliputi Sunda dan Jawa dipisahkan oleh sebuah sungai yang bernama Chemano (Cimanuk). Kerajaaan Sunda dengan kota besarnya Dayo (Bogor) memiliki enam pelabuhan, yaitu Bantam (Banten), Pondam (Pontang), Cheguide (Cigede), Tamgaram (Tangerang), Calapa (Jakarta), dan Chemano atau Cimanuk (Heuken, 1999).

Di wilayah Jawa terdapat beberapa pelabuhan, diantaranya adalah Cheroboam (Cirebon). Charabaon (Cirebon) terdapat dalam peta Asia yang dibuat oleh Mercator dan dilengkapi oleh Hondius (1606) di Amsterdam. Da Asia, Decada IV karya Joao De Barros ( \pm 1496 - 1570) yang diedit oleh Joao Baptista Lavanha tahun 1615 di Madrid Spanyol, dilengkapi peta pulau Jawa yang menggambarkan pelabuhan-pelabuhan di pesisir pantai utara Pulau Jawa diantaranya Charabom (Cirebon) disebelah timur River Chiamo atau sungai Cimanuk (Heuken, 1999).

Terkait masa lampau Cirebon, arsiparis Belanda, E.C. Godee Molsbergen, mencatat bahwa Cirebon pada zaman Hindu tidak terkenal, pada saat itu terdapat peninggalan prasasti di Kawali (Kabupaten Ciamis). Di daerah Talaga (Kabupaten Majalengka) ditemukan koleksi patung perunggu, dan sebuah danau keramat untuk upacara keagamaan masyarakat pribumi yang tidak boleh dikunjungi oleh bangsa Eropa. Peristiwa penting dalam keagamaan di Cirebon adalah kedatangan seorang warga Arab, seorang penyebar agama Islam, terkenal dengan nama Syekh Israel Ibn Maulana, Falatehan, atau Susuhunan Gunung Jati. Pada saat kedatangannya, masyarakat menghormati beliau dengan mempersembahan sebuah piring yang berisi sari godokan udang yang dinamakan peter (petis). Daerah yang awalnya bernama Pakungwati, setelah itu dinamakan Cai-rebon atau Cirebon. Orang-orang Portugis menulisnya Charabon. Di dalam dokumen VOC ditulis Tsjeribon, Chirrebon, Sirrebon, Cheribon (Molsbergen, 1931).

Naskah Carita Purwaka Caruban Nagari (CPCN) karya Pangeran Aria Carbon ditulis tahun 1720 Masehi, mencatat dengan lengkap nama nagari-nagari pesisir atau kerajaan kecil bawahan Kerajaan Pajajaran, yaitu Nagari Surantaka, Singapura, dan Nagari Japura. Dalam perkembangannya nagari-nagari pesisir ini sangat berperan dalam pembentukan wilayah Kerajaan Islam Cirebon. Nagari Singapura mencapai masa kejayaan sekitar tahun 1415 Masehi, wilayahnya meliputi kampung Pasambangan dan pelabuhan Muarajati. Ki Gedeng Tapa menjadi syahbandar pelabuhan Muarajati dengan gelar Ki Gedeng Jumajanjati. Selanjutnya pelabuhan Muarajati menjadi ramai karena berbagai perahu berlabuh di situ. Diantara perahu-perahu itu berasal dari 
negeri Cina, Arab, Persi, India, Malaka, Tumasik (kini negara Singapura), Pasai, Jawa Wetan, Madura, dan Palembang. Diceritakan pula pembangunan mercusuar di Gunung Amparan Jati oleh angkatan bersenjata Cina yang dipimpin Panglima Besar Wa Hengping dan Laksamana Te-Ho (Cheng-Ho). Mercusuar tersebut memandu kapal-kapal ke pelabuhan Muarajati. Pekerjaan pembangunannya dibayar oleh Ki Gedeng Jumajanjati dengan garam, terasi, beras tumbuk, rempah-rempah, dan kayu jati (Atja, 1986).

Di selatan Cirebon terdapat Gunung Ciremai (3.078 mdpl), adalah gunung tertinggi di wilayah Jawa Barat, keberadaannya merupakan lanskap alami (natural landscape) yang mempengaruhi dan membentuk lanskap budaya (cultural landscape). Lanskap alami merupakan bentuk bentang alam yang relatif asli, hasil dari fenomena atau perwujudan muka bumi yang dipengaruhi oleh waktu terhadap faktor geologi, iklim, dan vegetasi. Adapun lanskap budaya adalah suatu bentuk bentangan alam yang merupakan hasil interaksi manusia dengan lanskap alaminya, sehingga muncul fiturfitur fisik (pemandangan/scenery, bangunan bersejarah, dan sebagainya) dan sosial yang memberi nilai (makna dan sejarah) yang melekat pada lanskap tersebut. Ekosistem dan habitat dari kedua lanskap tersebut memiliki ciri yang berbeda tergantung dari tingkat intervensi manusia terhadap lanskapnya. Kategorisasi elemen-elemen lanskap yang bersifat fisik, dikelompokan berdasarkan (1) bentuk muka bumi/topografi; (2) Karakter elemen alami (natural) seperti gunung, sungai dan sebagainya; (3) struktur dan buatan (man made) seperti bangunan dan sebagainya, (4) elemen keras (hard) seperti lampu jalan dan sebagainya, serta (5) elemen lembut (soft) seperti tanaman, air, dan lainnya (Rosmalia, 2016).

Tulisan ini mengkaji permasalahan karakter alami Gunung Ciremai yang telah mengalami beberapa kali erupsi dan gempa bumi. Aliran lahar yang membawa material vulkanik mengalir turun ke muara sungai-sungai, dan terjadi proses sedimentasi sungaisungai yang berdampak pada perubahan fisik morfologi tata ruang Kota Cirebon khususnya kawasan pelabuhan Cirebon yang berada di daerah hilir. Metode untuk menganalisis permasalahan tersebut menggunakan metode arkeologi sejarah dengan mengkaji sumber-sumber arsip primer dan sekunder, arsip statis bernilai sejarah, arsip kartografi, dan arsip litografi yang di analisis dengan peta Citra Satelit. Data hasil analisis kemudian diverifikasi dengan data-data hasil observasi lapangan di pelabuhan Cirebon pada tahun 2019.

\section{PEMBAHASAN}

Visualisasi terkait kondisi Pelabuhan Cirebon dan Panorama Gunung Ciremai setidaknya pada sekitar 250 tahun silam dapat ditemukan pada khazanah arsip di Perpustakaan Nasional Jakarta berupa lukisan masa VOC. Ada dua buah lukisan karya seniman VOC bernama Johannes Rach (1720-1783), dilukis sekitar tahun 1775 dengan menggunakan media kuas dan tinta pada sehelai kertas berukuran 35,5 x $52 \mathrm{~cm}$ (Gambar 1).

Lukisan pertama berjudul Het Gezigt van Cheribon van de Rhee te zien Leggende op het Grotte Eiland Iava memberikan gambaran Cirbon Revier (pelabuhan 
Cirebon) dan benteng De Beschermingh Cheribon. Digambarkan dari arah timur laut menghadap ke barat pelabuhan Cirbon Revier dengan dermaga yang ramai dengan lalu lalang kapal dagang VOC berbendera Belanda. Dari garis pantai terdapat dermaga dan kanal pelabuhan melewati jembatan gantung sebagai akses keluar-masuk ke pelabuhan dan gerbang benteng yang mungkin pada saat itu bisa dibuka dan di tutup agar kapal dagang dapat masuki pelabuhan Cirebon. Posisi jembatan gantung ini diperkirakan sekarang berada di lampu merah persimpangan Jalan Benteng dengan Jalan Pabean, depan pintu utama Pelabuhan Cirebon. Di sisi selatan Cirbon Revier terdapat Benteng De Beschermingh Cheribon dengan pergudangannya dan tiang bendera Belanda yang berkibar di tepian pantai. Di sisi utara Cirbon Revier masih berupa tanah lapang di tepian pantai yang disandari perahu-perahu kecil nelayan setempat untuk bongkar hasil melaut dan memperbaiki perahu-perahu yang rusak. Dari timur pantai ini ke barat terdapat Kota Cirebon dengan deretan bangunan-bangunannya.
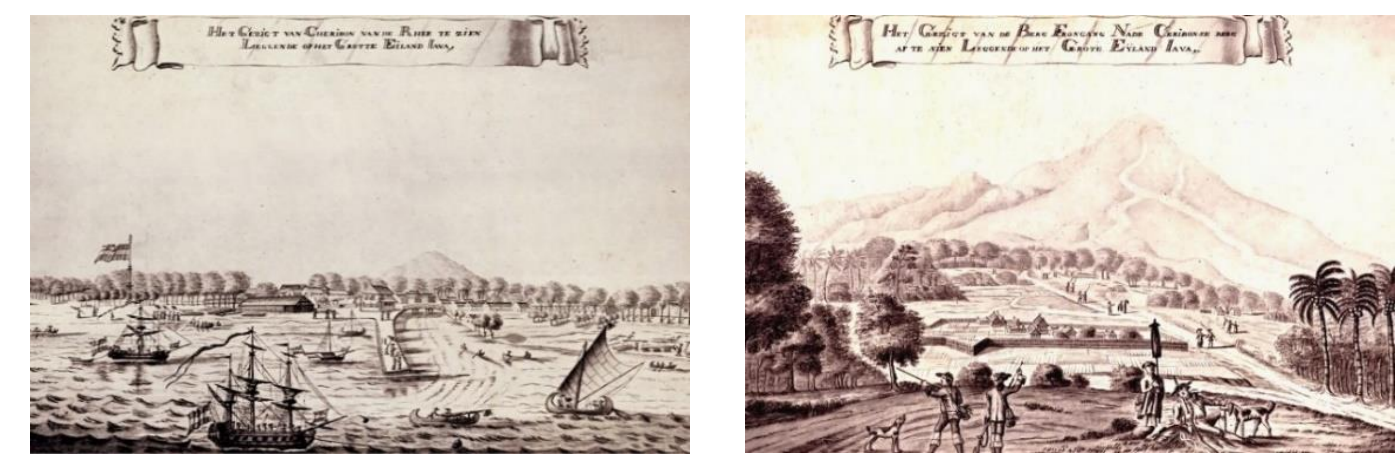

Gambar 1. Lukisan Panorama pelabuhan Cirebon dan Gunung Ciremai tahun 1775 karya Johannes Rach (1720-1783). (Sumber: Perpusnas RI, Uits Cheribon's Geschiedenis, Gedengboek der Gemeente Cheribon 1906-1931, halaman 12 dan 16).

Lukisan kedua berjudul Het Gezigt van de Berg Frongang Nade Ceribonse berg at te sien Leggende op het Grotte Eyland Iava, gambaran panorama lereng Gunung Ciremai atau de Berg Frongang, dekat Kota Cirebon tahun 1775. Lukisan menggambarkan tiga orang Eropa sedang berburu dan menikmati kesejukan pagi hari panorama Gunung Ciremai sebagai hiburan mereka. Meskipun skala lukisan kurang tepat dengan objeknya, tergambar bekas erupsi Gunung Ciremai dengan dua jalur lahar bercabang dari puncak gunung ke bawah. Tidak jelas dari arah mana lukisan itu dibuat, diduga dilukis dari suatu tempat yang tinggi seperti daerah Linggarjati (Molsbergen, 1931).

\section{Cirebon Revier, Pelabuhan Cirebon Masa VOC}

Pelabuhan Kota Cirebon yang sekarang pada awalnya adalah pelabuhan yang digunakan oleh Kongsi Dagang Hindia Timur atau Vereenigde Oost-Indische Compagnie disingkat VOC sejak akhir Abad XVII-XVIII, dan selanjutnya dikembangkan oleh Pemerintah Kolonial Hindia Belanda pada pertengahan Abad XIX dengan dibangun pelabuhan baru di pesisir pantai Kota Cirebon di sebelah utara kanal 
pelabuhan lama. Pelabuhan ini pada awalnya adalah sebuah sungai tua yang dalam arsip kartografi kolonial Hindia Belanda disebut Cirbon Revier yang terletak di sisi utara benteng VOC yaitu benteng De Beschermingh Cheribon. Dibangunnya Pelabuhan Cirebon tersebut dilatarbelakangi oleh beberapa kali letusan Gunung Ciremai yang mengakibatkan tingginya sedimentasi, dan meledaknya gudang mesiu (bahan peledak) dalam benteng akibat kecerobohan seorang kopral penjaga benteng. Reruntuhan ledakan benteng De Beschermingh Cheribon menimbun kanal pelabuhan Cirbon Revier yang letaknya berada di sebelah utara benteng.

Pada tanggal 7 Januari 1681, VOC berhasil menandatangani kontrak internasional pertama dengan Kasultanan Cirebon. Isi kontrak menyepakati bahwa Cirebon bukan lagi vasal Susuhunan Mataram, Cirebon menjadi wilayah protektorat VOC yang berhak memonopoli perdagangan: lada, beras, kayu, gula, dan mengimpor opium, candu, serta diizinkan membangun loji atau benteng perlindungan di Cirebon.

Pada 8 Maret 1686 kesepakatan pembangunan loji atau Benteng Cirebon direalisasikan dengan pembangunan benteng berbentuk empat persegi dilengkapi dengan senjata meriam untuk keamanan dan pertahanan benteng. Benteng De Beschermingh Cheribon adalah tempat tinggal residen sebagai pejabat VOC yang tugasnya sebagai perantara perdagangan antara VOC dan para Sultan Cirebon serta para pemimpin pribumi lainya. Residen juga bertugas mempertahankan keseimbangan jika ada perselisihan antara Sultan Cirebon atau para Pangeran. Dengan demikian benteng Cirebon berfungsi sebagai tempat perlindungan sekaligus pusat pemerintahan dan perdagangan VOC. Selain untuk tempat tinggal para pegawai Kompeni, di dalam benteng terdapat juga penjara dan gudang-gudang.
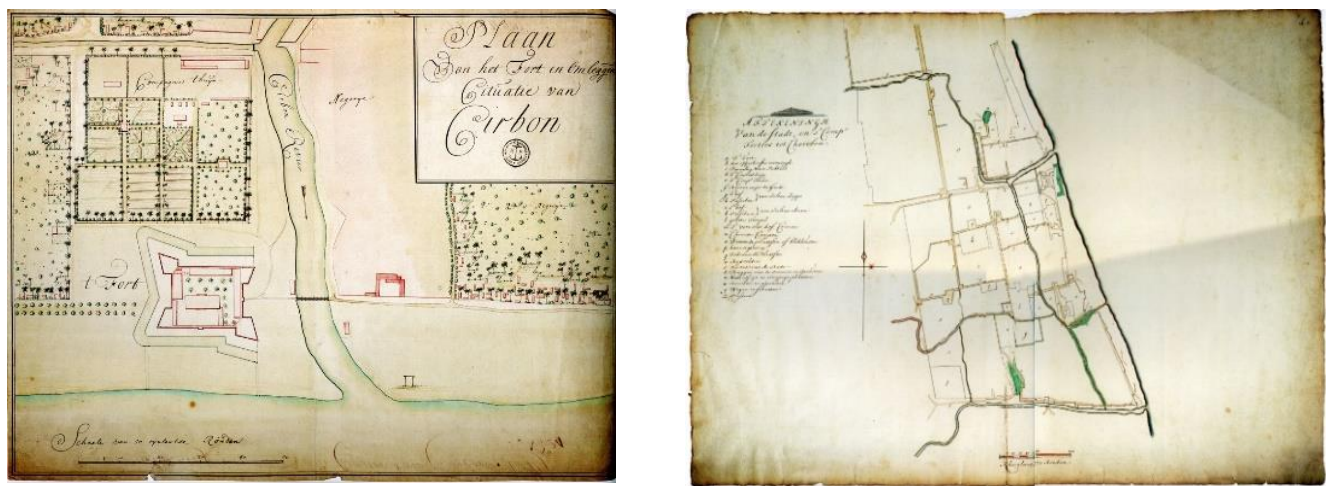

Gambar 2. Peta Tata Ruang Kota Cirebon masa VOC. (Sumber: National Archive Nederlands Den Haag, 4,VEL. 1250; National Archive Nederlands Den Haag, 4.VEL. 1252).

Berdasarkan analisa peta-peta kuna VOC dan peta Citra Satelit, lokasi Benteng De Beschermingh Cheribon dapat direkonstruksi sebagai berikut. Lokasi benteng berada di sisi barat teluk Cirebon menghadap ke utara, di depan pintu gerbang benteng sebelah utara dibatasi Cirbon Revier sebagai kanal pelabuhan (Pabean) yang diproteksi dan dimonopoli oleh VOC (sekarang menjadi Jalan Pabean). Di sebelah barat benteng terdapat perumahan pegawai VOC yang dibatasi Kali Batjin (sekarang Jalan Talang - 
Jalan Merdeka), berbatas dengan kawasan Keraton Kanoman. Kanal Cirbon Revier yang dijadikan pelabuhan oleh VOC adalah muara dari beberapa cabang sungai yang mengalir bermuara ke teluk Cirebon.

Keraton Kasepuhan terletak di sebelah utara sungai Krian/Kasunean, sebelah utara dari Keraton Kasepuhan dibentengi oleh Sungai Sipadu, disebelah timur Keraton Kasepuhan dibentengi oleh anak Sungai Kasunean - Sipadu (sekarang menjadi Jalan Mayor Sastra Atmaja), sedangkan di sebelah barat dibatasi oleh anak sungai yang mengalir dari Sungai Krian - Sipadu (sekarang menjadi Jalan Pegajahan). Keraton Kanoman berada di sebelah utara dari Keraton Kasepuhan, di sebelah selatan berbatas Jalan Pulasaren, di timur Jalan Lemahwungkuk, di utara Jalan Kanoman, serta di bagian barat setelah perempatan Jagabayan dari utara ke selatan terdapat Jalan Winaon sampai Jalan Kepatihan - Jalan Pulasaren (sekarang terputus karena bangunan perumahan penduduk). Adapun jaringan jalan lainya yang telah ada yaitu: Jalan Pasuketan - Jalan Pekiringan (Wegh na Panjelan), dan Jalan Pulasaren - Jalan Lawanggada (menuju arah Kuningan). Jalan utama Cirebon - Gunung Jati adalah Jalan Karanggetas (Gambar 2).

\section{Erupsi Gunung Ciremai dan Pengaruhnya}

Menurut N.J.M. Taverne yang melakukan studi tentang gunung-gunung di Jawa (Gambar 3) dalam karyanya Vulkaanstudien Op Java (1926). Gunung Ciremai seperti Gunung Slamet, adalah gunung berapi yang berdiri sendiri yang mendominasi lanskap alami sejauh mata memandang, titik puncak tertinggi adalah 3.078 mdpl. Di atas ketingian 2000 meter Gunung Ciremai memiliki bentuk kerucut murni, tetapi di bawahnya memiliki jalur yang kurang teratur. Gunung Ciremai dalam arsip kolonial memiliki beberapa nama, yaitu De Berg Sirmey, De Berg Frongang Nade Ceribonse berg, Tjerimai (Cerimai), dan Tjiremai (Ciremai). Menurut Junghuhn nama Cerimai berasal dari nama buah tejerme (mungkin cerme, atau Phyllanthus acidus ), tetapi menurut Taverne hal ini tidak mungkin karena pohon yang menghasilkan buah cerme tidak ada di Gunung Ciremai. Menurut van Gent, Cerimai berarti Schoone regenberg, Ceri berati cantik, dan meha berarti gunung hujan, atau gunung hujan yang cantik (Taverne, 1926). Dalam Sejarah Wali Syekh Syarif Hidayatullah Sunan Gunung Jati Naskah Mertasinga disebut Giri Carme tempat untuk mecarmenan (musyawarah) Sunan Gunung Jati dan Walisanga membahas ilmu dan strategi dakwah Islam (Wahyu, 2005).

Dalam Almanak En Naamregister Van Nederlandsch-Indie Hal 23, 1845 menurut pengukuran yang dilakukan oleh Junghuhn, tinggi puncak kawah gunung Tjerimei 9731 kaki $(1$ kaki $=0,3048$ meter $=30,48 \mathrm{~cm})$, dan ketinggian kampung Argalingga 3880 kaki. Selanjutnya dalam Almanak En Naamregister Van Nederlandsch-Indie hal. 33, 1848 Junghuhn mencatat ketingian beberapa desa dan gunung di sekitar Gunung Ciremai sebagai berikut. (1) Kuningan (rumah Controleur) 1754 kaki, (2) Desa Ciniru 807 kaki, (3) Gunung Pugag (Pas Jalan) 2726 kaki, (4) Desa

Selogambe 1014 kaki, (5) Gunung Kiara Nongkeng (Pas Jalan) 2235 kaki, (6) Desa Ciwaru 543 kaki, (7) Desa Camara 822 kaki, (8) Desa Luragung 310 kaki, dan (9) 
Gunung Maningtang (puncak tertinggi di tepi kiri sungai) setinggi 231 kaki.

Dari catatan sejarah menurut Junghuhn hanya diketahui dua kali letusan Gunung Ciremai, yaitu pada tahun 1772 dan tahun 1805. Junghuhn tidak menginformasikan catatan apapun tentang bekas letusan tersebut yang terjadi bersamaan dengan bencana besar Gunung Papandayan. Ketika Junghuhn mendaki Gunung Ciremai pada tahun 1837, menemukan pohon pada ketinggian 200 meter di bawah puncak Ciremai yang berumur 32 tahun lebih tua dari sejak letusan terakhir. Di tempat yang lebih tinggi vegetasi menunjukkan semua tanda-tanda usia mudanya. Dengan demikian dapat disimpulkan hanya tumbuh-tumbuhan di bagian atas gunung Ciremai yang hancur oleh lemparan batu, abu dan pasir pada saat letusan tahun 1805 (Taverne, 1926).

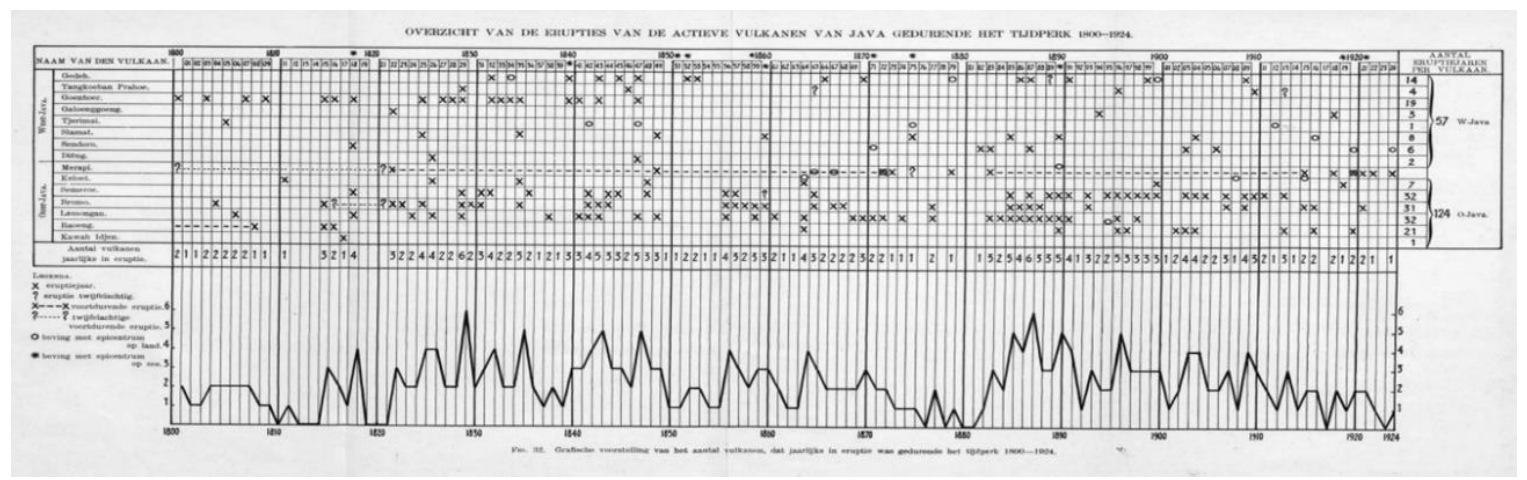

Gambar 3. Data erupsi gunung berapi di Pulau Jawa sejak tahun 1800-1924. (Sumber: Taverne, Ir. N.J.M. 1926. Vulkaanstudien Op Java.).

Akibat letusan tersebut Kota Cirebon selama tahun 1772-1773 dan 1805-1806 mengalami wabah epidemi yang hebat sekali antara lain muntaber yang telah menewaskan 1/4 bagian penduduknya. Pada tahun 1817 banyak ditemui penguburan mayat yang sembarangan dengan bau busuk yang menyengat di dalam Kota Cirebon. Hal ini akibat tidak adanya saluran pembuangan air kotor di dalam Kota Cirebon. Orang-orang pribumi menguburkan jenazah kurang dalam dan berada di dekat perumahan mereka. Banyak bangunan yang terbuat dari batu bata yang kosong dikelilingi pagar tembok tinggi menjadi tempat pembuangan sampah, air comberan, kotoran manusia, pembuangan air kolam para sultan, tanah paya, tempat pembuangan ikan yang sudah busuk apabila para nelayan terlambat mendarat di pelabuhan. Kondisi demikian ini sangat memalukan citra Kota Cirebon, dan orang pribumi sendiri sangat merasakan kesulitan untuk membawa hasil-hasil bumi dari pedalaman ke Pelabuhan (Molsbergen, 1931).

Erupsi Gunung Ciremai memperburuk kondisi pelabuhan Cirebon dan benteng De Beschermingh Cheribon. Pada tahun 1804-1806 menurut John Joseph Stockdale, di tepian kanan sungai sisi laut ada sebuah benteng batu bata kecil, yang dikelilingi parit pertahanan dan di atasnya terdapat jembatan dengan kubu pertahanan. Benteng ini tidak begitu penting, tebal dinding pertahanannya hanya 18 inci, dilengkapi dengan empat meriam kecil. Benteng kurang kokoh untuk menjaga bendera Belanda dan 
menjawab salut dari kapal-kapal yang melintas dan masuk. Dermaga pelabuhan sangat buruk, sisi kiri sudah benar-benar runtuh dan sebagian besar sudah lenyap. Di sisi kanan masih ada sisa dermaga pelabuhan tetapi susunannya sudah hancur, atau berlepasan. Sudah dipertimbangkan untuk membangun benteng baru dengan dilengkapi sebuah meriam di ujungnya, dan juga dua meriam untuk masing-masing sisinya, sebagai pertahanan untuk melawan bajak laut yang terus menerus menggangu daerah ini. Garnisun terdiri dari 15 orang Madura dengan senjata api yang sangat buruk, dipimpin oleh seorang sersan dan dua kopral Eropa (Stockdale, 2014).

Pada 31 Oktober 1835 terjadi ledakan di gudang mesiu yang berada di dalam benteng, bangunan utama benteng ini hancur total sehingga harus dirobohkan. Gedung yang berada di luar benteng tidak meninggalkan sisa-sisa pilar, kaca jendela maupun genteng akibatnya sungai pelabuhan Cirbon Revier dan dermaganya tertimbun reruntuhan, juga kanal-kanal di sekelilingnya menjadi tersumbat. Sebagai ganti benteng De Beschermingh Cheribon yang hancur total, pemerintah kolonial Hindia Belanda kemudian segera membangun kembali kawasan pusat pemerintahan baru yang dikenal dengan sebutan Keboemen Plein sebagai pusat pemerintahan Karesidenan Cirebon. Keboemen Plein dibangun dengan sistem tata ruang bangunan pemerintahan kolonial yang sentralistik dan kapitalis monopolistik. Mula-mula dibangun Resident Kantoor (Kantor Residen) pada tahun 1841, namun pada tahun 1847 terjadi gempa bumi yang menghancurkan beberapa bangunan pemerintahan, terutama bangunan rumah Residen Cirebon. Selanjutnya pelabuhan VOC Cirbon Revier yang telah hancur mulai diurug pada tahun 1855. Pada tanggal 25 Oktober dan 29 Nopember 1875, terjadi gempa bumi yang menghancurkan daerah Kuningan, terjadi tanah longsor dari Gunung Ciremai dan beberapa jembatan hancur (Molsbergen, 1931).

\section{Pelabuhan Cirebon Tanjung Mas}

Untuk mengatasi keadaan tingginya sedimentasi, juga karena tertimbunnya kanal pelabuhan Cirbon Revier yang hancur akibat ledakan benteng, sejak tahun 1865 dari muara pelabuhan lama Cirbon Revier dibangun saluran selebar sekitar 20 meter dengan dibatasi dinding penyangga dermaga setebal sekira 1.50 meter di kiri kanannya sepanjang sekitar 200 meter garis pantai (Baggelaar, 1931). Mulai 1 Juli 1867 kapalkapal yang keluar masuk ke pelabuhan Cirebon dipandu dengan mercusuar setinggi 14 meter lengkap dengan ruang jaga terbuat dari konstruksi besi dengan pondasi batu beton dan pada bulan Juli 1883 lampu lentera lama mercusuar diganti dengan lichtopstand vervangen atau lampu dengan dudukan (Regeerings Almanak Voor Nederlandsch-Indie (RANI) 1884, .Bijlage UU).

Memasuki awal Abad XX sampai dengan tahun 1920-an Kawasan Pelabuhan Cirebon mulai terbentuk sebagai pelabuhan modern (Gambar 4). Area Pelabuhan Cirebon sepanjang Jalan Pasisirweg (Jalan Pesisir sekarang Jalan Sisingamangaraja XII) di sisi barat laut, sebelah utara dibatasi oleh sungai Kali Anyar yang bermuara ke laut. Batas selatan adalah kanal Cheribon Rivier (bekas Pelabuhan Lama) yang bermuara ke laut lepas. 
Akses masuk dan keluar pelabuhan Cirebon dapat ditempuh dari beberapa jalan. Dari arah timur-selatan dapat melalui Jalan Cangkol (sekarang Jalan Yos Sudarso) menuju pintu utama Pelabuhan Cirebon, dan dari arah selatan-barat melalui Jalan Pasuketan - Jalan Pabean ke pintu utama Pelabuhan Cirebon. Dari arah utara menuju pelabuhan melalui Jalan Pakoetoekan (sekarang Jalan Kapten Samadikun) melewati jembatan Kali Anyar sepanjang Pasisirweg melewati Gevangenis (Penjara Pelabuhan) dan pergudangan pelabuhan (sekarang pergudangan Yala Gita Tama) sampai pertigaan jalan berbelok ke kiri masuk ke kawasan pelabuhan di depan Douanekantoor (Kantor Beacukai) dan dermaga 1 Pelabuhan Cirebon. Dari Pergudangan Yala Gita Tama, jika berbelok ke kanan melewati Jalan Kendoeroean (Kenduruan) menuju daerah Panjoenan (Panjunan). Dari Masjid Merah Panjunan lurus ke Jalan Kolektoran sampai Jalan Karanggetas, jika berbelok ke kanan menuju pergudangan Pekaroengan (Pekarungan).
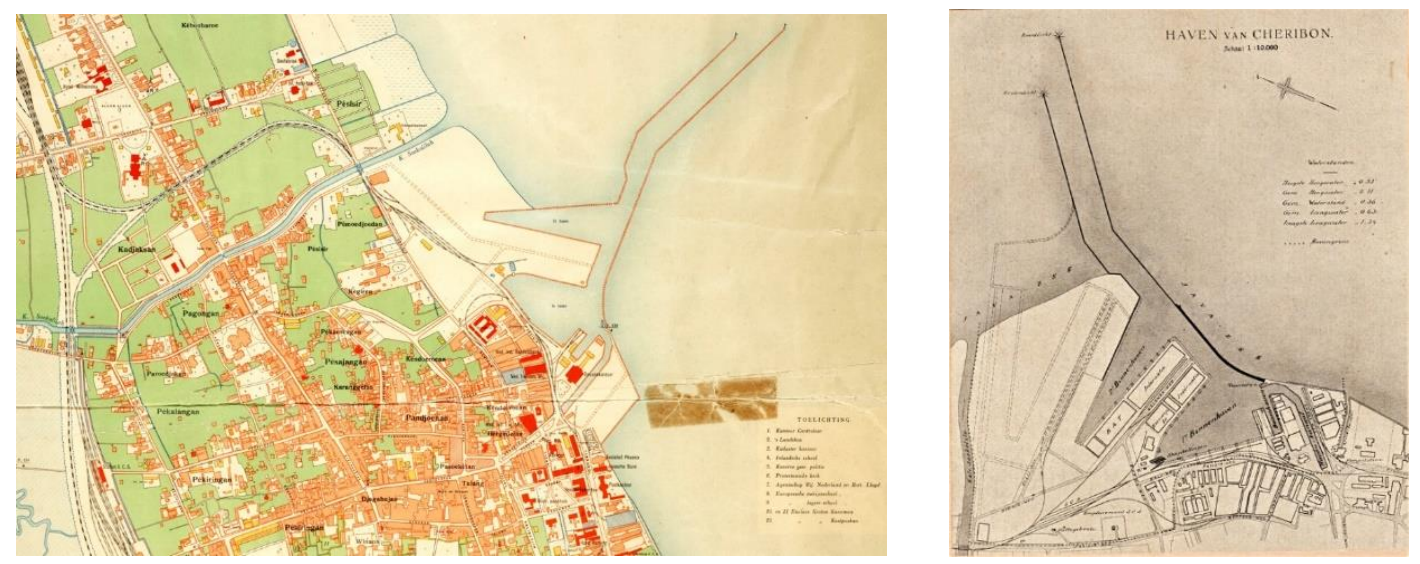

Gambar 4. Peta Tata Ruang Pelabuhan Cirebon tahun 1921 (kiri) dan 1931 (kanan). (Sumber: Dutch Colonial Maps Leiden Universiteit, Hoofdplaats Cheribon, Name: 03933; Gedengboek der Gemeente Cheribon 1906-1931, halaman 146 ).

Di dalam area pelabuhan masuk melalui pintu utama dari arah selatan ke utara di sisi barat dermaga pelabuhan berjajar kantor dan pergudangan NHM (Ned. Handels Mij.) dan NIHB (Ned. Ind. Handels Bank), Zoutpakhuizen (Gudang Garam), dan Gevangenis (Penjara Pelabuhan). Douanekantoor (Kantor Beacukai) berada di sisi utara kanal pelabuhan lama. Aktivitas bongkar muat di pelabuhan masih dilakukan di kanal pelabuhan lama dan dermaga 1. Pada saat itu dermaga 2 baru setengah pengerjaannya. Di sepanjang batas sisi utara pelabuhan Kali Anyar masih berupa tanah kosong yang terus bertambah luasnya karena sedimentasi Kali Anyar (hulunya bernama Kali Sukalila), masyarakat setempat menyebut tanah kosong itu Karang Kletak. Sejak tahun 1897 jalur rel trem uap mulai dibangun di pelabuhan Cirebon. Jalur rel trem uap ini dibangun oleh perusahaan kereta api swasta Semarang - Cheribon Stoomtram Maatschappij (SCS), di bangun juga bangunan halte SCS di sebelah barat Karang Kletak, yang kini menjadi kawasan Rumah Sakit Pelabuhan Cirebon. Sejak tahun 1901 dari pelabuhan Cirebon jalur rel trem uap terhubung ke wilayah barat Cirebon sepanjang 50 Kilometer sampai Kota Kadipaten, Majalengka. Tahun 1912 beroperasi 
jalur rel kereta api negara dari Cikampek menuju Cirebon melalui Stasiun SS (Staats Spoorwegen) Cheribon.
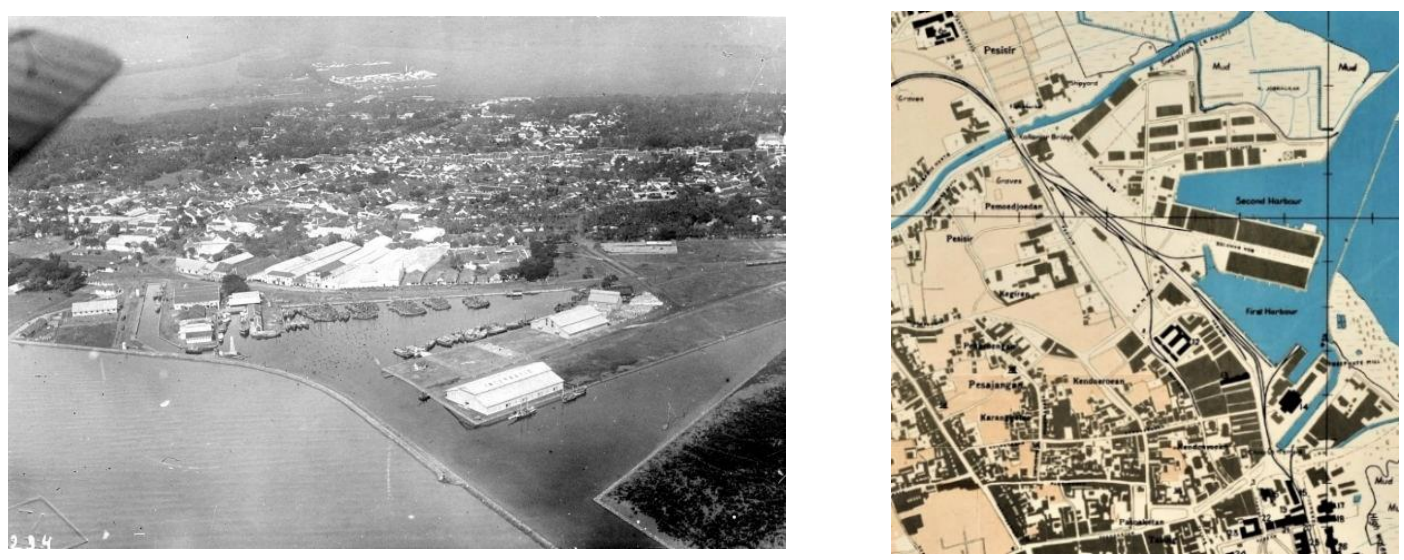

Gambar 5. Foto udara Pelabuhan Cirebon tahun 1930 (kiri) dan Peta Tata Ruang Pelabuhan Cirebon 1931/1946 (kanan). (Sumber: (Foto) Collectie Tropenmuseum nl. TMnr 10007983, (Peta) Perpustakaan Nasional RI).

Perkembangan selanjutnya hingga tahun 1931 (Gambar 5) kondisi Pelabuhan Cirebon mengalami pembangunan insfrastruktur pelabuhan dan penunjang lainnya. Antara dermaga 1 dan dermaga 2 dibangun gudang-gudang terutama: Gudang Pabrik Rokok Britisch American Tobacco (BAT), gudang Internatio, dan gudang Escompto Bank (kondisi sekarang bangunan tersebut sudah rata dengan tanah). Di sebelah utara dari dermaga 1 sudah terbentuk jaringan jalan yang bersebelahan dengan rel kereta api seperti Banka Weg (Jalan Bangka), Belawan Weg (Jalan Belawan) di tengah kompleks pergudangan BAT, Internatio, dan Escompto. Di sisi timur Halte SCS Pelabuhan terdapat Emplacement SCS dengan sederetan jalur rel dan persimpangan menuju gudang-gudang pelabuhan. Dari arah utara pintu pelabuhan Cirebon sudah terdapat Borneo Weg (Jalan Borneo) yang bercabang ke Deli Weg (Jalan Deli) menuju dermaga 2, dan Belawan Weg (Jalan Belawan) di dermaga 1. Kondisi tersebut berlangsung hingga masa akhir pemerintahan Hindia Belanda tahun 1942.

\section{SIMPULAN}

Erupsi Gunung Ciremai dengan berbagai dampaknya sangat berpengaruh terhadap kehidupan dan perkembangan morfologi tata ruang Kota Cirebon terutama pelabuhan Cirebon yang berada di wilayah hilir. Lahar dan debu vulkanik akibat letusan gunung Ciremai mengalir ke muara sungai membentuk lumpur aluvial dan mempertinggi sedimentasi di Daerah Aliran Sungai (DAS) di Kota Cirebon. Akibat tingginya sedimentasi dan ledakan benteng De Beschermingh Cheribon yang menimbun kanal pelabuhan tua Cirbon Revier tersebut tidak berfungsi maksimal, sehingga dibangun kembali pelabuhan baru dengan sistem dermaga dan kolam, serta fasilitas pergudangan modern berupa kawasan Pelabuhan Cirebon sekarang. 


\section{UCAPAN TERIMA KASIH}

Terima kasih disampaikan kepada Bapak Prof. Dr. Agus Aris Munandar, Dr. Iwan Hermawan, M.Pd., dan Mitra Bestari yang telah memotivasi dan membimbing penulis, Mas Muchlisul Amal yang telah menunjukan data kondisi pendakian Gunung Ciremai, serta pihak-pihak yang membatu sehingga artikel ini dapat selesai disusun.

\section{DAFTAR PUSTAKA}

Almanak En Naamregister Van Nederlandsch-Indie hal. 33. (1848). Batavia Ter Lands Drukkerij 1845. Halaman 23. Perpustakaan Arsip Nasional Republik Indonesia Almanak En Naamregister Van Nederlandsch-Indie Hal 23. (1845). Batavia Ter Lands Drukkerij 1845. Halaman 23. Perpustakaan Arsip Nasional Republik Indonesia Atja, S. (1986). Carita Purwaka Caruban Nagari, Karya Sastra Sebagai Sumber Pengetahuan Sejarah. Bandung: Pusat Pengembangan Permuseuman Jawa Barat. Baggelaar, J. . (1931). De Haven Van Gedenkboek der Gemeente Cheribon 1906-1931. Bandoeng-Cheribon, Gedrukt Bij de NVAC Nix \& Co, Op 1 April (Door De Stadgemeente Cheribon Uitgegeven Ter Gelegenheid Van Het 25).

Heuken, A. S. (1999). Sumber - Sumber Asli Sejarah Jakarta (sampai dengan tahun 1630) Jilid I. Yayasan Cipta Loka Caraka.

Molsbergen, D. E. C. G. (1931). Uits Cheribon's Geschiedenis, Gedengboek der Gemeente Cheribon 1906-1931. Bandoeng-Cheribon, Gedrukt Bij de NVAC Nix \& Co, Op 1 April(Door De Stadgemeente Cheribon Uitgegeven Ter Gelegenheid Van Het 25 - Jarig Bestaan Der Gemeente).

Regeerings Almanak Voor Nederlandsch-Indie (RANI) 1884. Eerste Gedeelte: Grondgebied, Bevolking, En Inrichting Van Het Bestuur Van Nederlandsch-Indie. Batavia - Landsdrukkerij 1883. Bijlage UU. Halaman 412-413. Perpustakaan Arsip Nasional Republik Indonesia

Rosmalia, D. (2016). Pengaruh Kebudayaan Keraton terhadap Pola Ruang Lanskap Budaya Cirebon. Sekolah Arsitektur Perencanaan dan Pengembangan Kebijakan, Program Studi Doktor Arsitektur. Bandung: Institut Teknologi Bandung.

Stockdale, J. J. (2014). The Island of Java Sejarah Tanah Jawa. Yogyakarta: Indolierasi. Taverne, I. N. J. . (1926). Vulkaanstudien Op Java. Vulkanalogische Mededeelingen No.

7 Dienst Van Den Mijnbouw In Nederlandsch-Indie. 'S Gravenhage - Algemeene Landsdrukkerij.

Wahyu, A. N. (2005). Sejarah Wali Syekh Syarif Hidayatullah Sunan Gunung Jati (Naskah Mertasinga) Cetakan Pertama. Penerbit Pustaka.

\section{HASIL DISKUSI}

Tidak Ada Pertanyaan 